\title{
Identification of a 95 kDa putative adhesin from Actinomyces serovar WVA963 strain PK1259 that is distinct from type 2 fimbrial subunits
}

\author{
Christiane M. Klier, ${ }^{1}$ Paul E. Kolenbrander, ${ }^{1}$ Arlene G. Roble, ${ }^{1}$
} Maria L. Marco, ${ }^{1}$ Sharon Cross ${ }^{2}$ and Pauline S. Handley ${ }^{2}$

Author for correspondence: Paul E. Kolenbrander. Tel: +1301496 1497. Fax: +1 3014020396. e-mail: kolenbrander@yoda.nidr.nih.gov

1 Laboratory of Microbial Ecology, National Institute of Dental Research, National Institutes of Health, Bethesda, MD 20892, USA

2 Microbiology Research Group, School of Biological Sciences, Stopford Building, Manchester University, Oxford Road, Manchester M13 9PT, UK
The species Actinomyces serovar WVA963 is among the 20 bacteria most frequently isolated from human subgingival plaque. The interactions of this species with streptococci are inhibited by lactose, a function associated with type 2 fimbrial surface structures in Actinomyces naes/undii. Type 1 fimbriae mediate binding of cells to salivary proline-rich proteins. Specific polyclonal antisera against type 1 and type 2 fimbriae of $A$. naes/undii T14V revealed both types of fimbriae on Actinomyces serovar WVA963 strain PK1259. To investigate the role of type 2 fimbriae of strain PK1259 in Actinomyces-Streptococcus lactose-inhibitable coaggregations, spontaneous coaggregation-defective $\left(\mathrm{Cog}^{-}\right)$mutants that failed to coaggregate with streptococci were isolated; three were chosen for study. All three mutant strains synthesized type 1 fimbriae and a 59 kDa protein; mutant strains PK2415 and PK3092 synthesized type 2 fimbriae and a 57 kDa protein. In contrast, the $\mathrm{Cog}^{-}$strain PK2407 did not agglutinate with anti-type 2 antibodies or show the $57 \mathrm{kDa}$ band, suggesting that the $57 \mathrm{kDa}$ protein was the type 2 fimbrial subunit. Polyclonal antiserum raised against the Actinomyces serovar WVA963 strain PK2399, an antibiotic-resistant derivative of wild-type PK1259, blocked coaggregation between this strain and streptococci. Anti-PK2399 serum absorbed with mutant strain PK3092 bearing type 2 fimbriae retained its blocking ability. Surface sonicates of the parent and mutant strains were adsorbed to streptococcal cells and to lactose-agarose beads. Lactose eluates from both the streptococcal cells and the affinity beads were characterized by SDS-PAGE and corresponding immunoblots using antiPK2399 serum absorbed with $\mathrm{Cog}^{-}$mutant PK3092. These blots revealed a 95 kDa putative adhesin in the parent strain PK2399 that was absent in the $\mathrm{Cog}^{-}$mutant strain PK3092. These results suggest the presence of a putative $95 \mathrm{kDa}$ actinomyces adhesin distinct from the $57 \mathrm{kDa}$ type 2 fimbrial subunit and that this adhesin mediates lactose-inhibitable coaggregation with streptococci.

Keywords: oral actinomyces, adhesin, fimbriae, coaggregation

\section{INTRODUCTION}

Actinomyces are among the initial colonizers during early plaque development (Nyvad \& Kilian, 1987).
Besides their ability to bind to the tooth surface, they also interact with other genera of oral bacteria such as streptococci (Gibbons \& Nygaard, 1970), veillonellae (Hughes et al., 1988) or fusobacteria (Kolenbrander et al., 1989) as part of dental plaque (Kolenbrander \& London, 1993). Some of these coaggregations are mediated by a heat- and protease-sensitive actinomyces 
adhesin that binds to a cognate carbohydrate receptor on the streptococcal surface (McIntire et al., 1978). Oral actinomyces synthesize two different types of fimbriae; type 1 fimbriae bind to proline-rich proteins (PRPs) (Gibbons et al., 1988) present in saliva (Clark et al., 1984), and type 2 fimbriae are involved in lactoseinhibitable intergeneric coaggregations with streptococci (Cisar et al., 1983), as well as lactose-inhibitable binding to eukaryotic cells (Brennan et al., 1984, 1986). Type 2 fimbriae are present on all Actinomyces naeslundii strains so far examined, but type 1 fimbriae are not produced by all these actinomyces (Cisar et al., 1984; Johnson et al., 1990; Yeung, 1992).

The genes encoding the fimbrial subunits of type 1 and type 2 fimbriae of $A$. naeslundii strains $\mathrm{T} 14 \mathrm{~V}$ and WVU45 have been cloned and sequenced (Donkersloot et al., 1985; Yeung et al., 1987; Yeung \& Cisar, 1988, $1990)$. Both subunits are about $60 \mathrm{kDa}$ in size and contain the cell surface binding motif LPxTG in the Cterminal region that is characteristic of many Grampositive surface proteins (Schneewind et al., 1992, 1995). The deduced amino acid sequences of FimA (subunit of type 2 fimbriae) of A. naeslundii WVU45 and that of FimP (subunit of type 1 fimbriae) of $A$. naeslundii T14V are $34 \%$ identical (Yeung \& Cisar, 1990). The amino acid sequence homology between the FimA proteins of A. naeslundii WVU45 and $A$. naeslundii T14V is $70 \%$ (J. A. Donkersloot, personal communication; Yeung \& Cisar, 1988). Studies by Cisar and colleagues (Cisar et al., 1983, 1984) showed that A. naeslundii strains lacking FimA (type 2 fimbriae) have lost the ability to mediate lactose-inhibitable coaggregation with streptococci. However, it remains unclear if FimA possesses the lactose-sensitive adhesive function or if an accessory fimbrial protein is responsible (Cisar et al., 1991). The presence of FimP on the cell surface was shown to be insufficient for adherence to salivary PRPs (Yeung, 1995). A minor protein at the tip of the type 1 fimbriae has been proposed to mediate the binding of $A$. naeslundii T14V to salivary PRPs (Nesbitt et al., 1992).

This raised the question as to whether there may also be a distinct protein associated with FimA (type 2 fimbriae) or whether the FimA subunit itself provides the adhesive function. Examples of both possibilities have been documented for Gram-negative bacteria (Abraham et al., 1987; Irvin et al., 1989; Moch et al., 1987; Uhlin et al., 1985; Weiss et al., 1988). In Pseudomonas aeruginosa, the adhesive function is located in the C-terminal region of the $15 \mathrm{kDa}$ structural subunit of the type IV pili (Lee et al., 1994). In the oral bacterium Prevotella loescheii, a distinct $75 \mathrm{kDa}$ adhesin (London \& Allen, 1990 ) is located at or near the tips of fimbriae (Weiss et al., 1988). The extensively studied Escherichia coli PapG adhesin is found as part of a specialized structure at the tip of the P pili (Kuehn et al., 1992). Recent studies have also shown that the FimH adhesin of type 1 pili in E. coli is assembled into a fibrillar tip structure that is distinct from the fimbrial subunit (Jones et al., 1995).

To investigate the possibility that an actinomyces adhesin distinct from the type 2 fimbrial subunit may mediate lactose-inhibitable coaggregations with streptococci, we chose Actinomyces serovar WVA963 strain PK1259 because it interacts only by lactose-inhibitable coaggregations with its streptococcal partners (Kolenbrander et al., 1983). Spontaneously occurring mutants were selected for failure to coaggregate with streptococci and analysed and compared to the wildtype PK1259 for the presence of adhesins.

\section{METHODS}

Bacterial strains and culture conditions. All bacterial strains were of human origin and are listed in Table 1. The oral strain Actinomyces serovar WVA963 strain PK1259 was isolated from a subgingival site (Kolenbrander et al., 1983). Actinomyces and streptococci were grown at $37^{\circ} \mathrm{C}$ in CAMG medium (Maryanski \& Wittenberger, 1975) containing $\left(1^{-1}\right)$ : tryptone $(5.0 \mathrm{~g})$; yeast extract $(5.0 \mathrm{~g})$; glucose $(2.0 \mathrm{~g})$; dibasic potassium phosphate $(5.0 \mathrm{~g}) ; 0.5 \mathrm{ml}$ Tween 80 (Sigma); and adjusted to $\mathrm{pH} 7 \cdot 4$. Cells were grown under anaerobic conditions $\left[\mathrm{N}_{2} / \mathrm{CO}_{2} / \mathrm{H}_{2}(80: 10: 10\right.$, by vol.) $]$ in Gas Pak systems (BBL Microbiology Systems). Veillonellae and fusobacteria were cultivated as described previously (Hughes et al., 1988; Kolenbrander et al., 1989). Bacterial cells used for coaggregation were grown overnight, washed three times and resuspended in coaggregation buffer $\left(0.1 \mathrm{mM} \mathrm{CaCl}_{2}, 0.1 \mathrm{mM}\right.$ $\mathrm{MgCl}_{2}, 150 \mathrm{mM} \mathrm{NaCl}, 0.02 \%, \mathrm{w} / \mathrm{v}$, sodium azide buffered with $1 \mathrm{mM}$ Tris/ $\mathrm{HCl}$, pH 8.0).

Coaggregation assay. The coaggregation of the actinomyces strains with other oral bacteria was tested by the visual coaggregation assay (Kolenbrander \& Andersen, 1990). Cells were grown overnight, harvested, washed, resuspended in coaggregation buffer and adjusted to a concentration of about $1 \times 10^{9}$ cells ml ml $^{-1}$ [260 Klett units (red filter); KlettSummerson]. Equal amounts of each cell suspension $(100 \mu \mathrm{l})$ were mixed and scored for coaggregation. A score of 0 was given when, after mixing, no change in turbidity could be observed in the cell suspension; a maximum score of 4 was given when, after mixing, the coaggregated cells sedimented immediately, leaving a clear supernatant. Suspensions of each cell type individually showed no autoagglutination.

Selection for $\mathrm{Cog}^{-}$mutants. Strain PK2399, a spontaneous antibiotic-resistant derivative of PK1259, was used to obtain spontaneous $\operatorname{Cog}^{-}$mutants by selecting those that failed to coaggregate with their streptococcal partners as described previously (Kolenbrander, 1982). Strain PK2399 was obtained by successive plating of strain PK1259 on agar containing $1000 \mu \mathrm{g}$ streptomycin (Sigma) or $500 \mu \mathrm{g}$ spectinomycin (Sigma) (Table 1). A suspension $\left(10^{9}\right.$ cells $\left.\mathrm{ml}^{-1}\right)$ of strain PK2399 was mixed with a dense cell suspension $\left(10^{10}\right.$ cells $\left.\mathrm{ml}^{-1}\right)$ of the appropriate streptococcal partner and centrifuged at $400 \mathrm{~g}$ for 2 min to remove coaggregates. The supernatant fluid was collected and additional partner cells were added; the procedure was repeated until no visible aggregates were seen. The resulting mutant-enriched supernatant fluid was plated on antibiotic-containing media. Colonies were selected and tested for coaggregation with the streptococcal partner in microtitre wells (Kolenbrander, 1982). Isolates that appeared coaggregation-negative with the appropriate partner were purified on antibiotic media and retested to confirm the $\mathrm{Cog}^{-}$ phenotype. All $\mathrm{Cog}^{-}$strains were tested for coaggregation with the other streptococcal reference strains as well as with other strains of oral bacteria.

Electron microscopy. Strains of Actinomyces serovar WVA963 were prepared for negative staining by the method of Handley 
Table 1. Organisms used in this study

\begin{tabular}{|c|c|c|}
\hline Strain & Characteristics & Reference/source \\
\hline $\begin{array}{l}\text { Actinomyces serovar WVA963 } \\
\text { strain PK1259 }\end{array}$ & $\begin{array}{l}\text { Wild-type, reference strain for actinomyces coaggregation } \\
\text { group } F\end{array}$ & Kolenbrander et al. (1983) \\
\hline PK2399 & Parent, double-antibiotic-resistant derivative of PK1259* & This study \\
\hline PK2407 & $\mathrm{Cog}^{-}$mutant of PK2399 selected with C104 & This study \\
\hline PK2415 & $\mathrm{Cog}^{-}$mutant of PK2399 selected with C104 & This study \\
\hline PK3092 & $\mathrm{Cog}^{-}$mutant of PK2399 selected with 34 & This study \\
\hline Actinomyces naeslundii $\mathrm{T} 14 \mathrm{~V}$ & Expresses both type 1 and type 2 fimbriae & Cisar et al. (1988) \\
\hline Actinomyces naeslundii 5519 & Expresses only type 1 fimbriae & Cisar et al. (1988) \\
\hline Actinomyces naeslundii 147 & Expresses no fimbriae & Cisar et al. (1988) \\
\hline Streptococcus gordonii DL1 & Reference strain for coaggregation group 1 & $\begin{array}{l}\text { Kolenbrander \& Andersen } \\
\text { (1986) }\end{array}$ \\
\hline Streptococcus oralis $\mathrm{H} 1$ & Reference strain for coaggregation group 2 & $\begin{array}{l}\text { Kolenbrander \& Andersen } \\
\text { (1986) }\end{array}$ \\
\hline Streptococcus oralis 34 & Reference strain for coaggregation group 3 & $\begin{array}{l}\text { Kolenbrander \& Andersen } \\
\text { (1986) }\end{array}$ \\
\hline Streptococcus oralis $\mathrm{C} 104$ & Reference strain for coaggregation group 3 & $\begin{array}{l}\text { Kolenbrander \& Andersen } \\
\text { (1986) }\end{array}$ \\
\hline Streptococcus oralis $\mathrm{J} 22$ & Reference strain for coaggregation group 4 & $\begin{array}{l}\text { Kolenbrander \& Andersen } \\
\text { (1986) }\end{array}$ \\
\hline Streptococcus SM strain PK509 & Reference strain for coaggregation group 5 & $\begin{array}{l}\text { Kolenbrander \& Andersen } \\
\text { (1986) }\end{array}$ \\
\hline Streptococcus gordonii PK488 & Reference strain for coaggregation group 6 & $\begin{array}{l}\text { Kolenbrander \& Andersen } \\
\text { (1986) }\end{array}$ \\
\hline Veillonella atypica PK1910 & Reference strain for veillonellae coaggregation group I & Hughes et al. (1988) \\
\hline $\begin{array}{l}\text { Fusobacterium nucleatum } \\
\text { PK1594 }\end{array}$ & $\begin{array}{l}\text { Coaggregation partner of all actinomyces strains used in } \\
\text { this study }\end{array}$ & Kolenbrander et al. (1989) \\
\hline
\end{tabular}

*Resistant to $1000 \mu \mathrm{g}$ streptomycin $\mathrm{ml}^{-1}$ and $500 \mu \mathrm{g}$ spectinomycin $\mathrm{ml}^{-1}$.

et al. (1984, 1985). Cells were incubated statically for $48 \mathrm{~h}$, collected by centrifugation at $1500 \mathrm{~g}$, and washed three times in distilled water. The final pellet was resuspended to give a milky suspension. A drop of this suspension was placed on a Formvar-coated copper grid (400 mesh; Agar Aids) which had been carbon-coated in a Bio-Rad E6200 Turbo Coater and plasma glowed in a Fisons Instruments PT7150 RF Plasma Etcher. Bacteria were negatively stained with $1 \%(\mathrm{w} / \mathrm{v})$ methylamine tungstate (EM Scope). Micrographs of fimbriae were taken on a Hitachi 600 electron microscope at $100 \mathrm{kV}$, at magnifications of 60000 and 80000 .

Agglutination of whole cells with PRP-coated latex beads. PRPs bound to polystyrene latex beads (Polysciences) were prepared as described by Gibbons et al. (1988) and Hsu et al. (1994). As a control, bovine serum albumin was bound to latex beads. To test binding to PRPs, $100 \mu \mathrm{l}$ PRP-coated latex beads was mixed with $5 \mu$ l bacterial cell suspension $\left(1 \times 10^{9}\right.$ cells $\mathrm{ml}^{-1}$ ) in flat-bottom microtitre wells (Flow Laboratories). Agglutination was scored after overnight incubation at $4{ }^{\circ} \mathrm{C}$.

Immunological testing for type 1 and type 2 fimbriae on Actinomyces serovar WVA963 strains. IgG of rabbit antiserum R59 against type 1 fimbriae and IgG of rabbit antiserum R55 against type 2 fimbriae of $A$. naeslundii T14V were kindly provided by J. Cisar (Cisar et al., 1988). Agglutination of cells by these antibodies was tested by mixing $25 \mu l$ antibody $\left(100-0 \cdot 1 \mu \mathrm{g}\right.$ protein $\mathrm{ml}^{-1}$, final concentration) with an equal amount of Actinomyces serovar WVA963 cells $\left(5 \times 10^{8}\right.$ cells $\mathrm{ml}^{-1}$ in coaggregation buffer) in V-shaped microtitre plates (Dynatech Laboratories). Agglutination was scored after overnight incubation at $4^{\circ} \mathrm{C}$. Cells of $A$. naeslundii $\mathrm{T} 14 \mathrm{~V}$ were included as a positive control.

Anti-PK2399 serum. Antiserum was raised in New Zealand White rabbits by injection of $0.5 \mathrm{ml}$ containing $5 \times 10^{8}$ cells of Actinomyces serovar WVA963 strain PK2399, suspended in coaggregation buffer (without sodium azide) with an equal amount of Freund's complete adjuvant. Preimmune serum was withdrawn and the injection schedule was started with an intradermal inoculation. Boost injections without Freund's adjuvant were administered intravenously in the marginal ear vein at $9 \mathrm{~d}$ intervals thereafter. Two test bleeds followed by two production bleeds, 5 and $25 \mathrm{ml}$, respectively, were taken at $18 \mathrm{~d}$ intervals and two additional production bleeds were taken at $3 \mathrm{~d}$ intervals just prior to exsanguination on day 80 . Antisera were screened for the ability to agglutinate strain PK2399 and to block coaggregation between strain PK2399 and its streptococcal partners, strains 34 and C104.

Antiserum absorption with $\mathrm{Cog}^{-}$mutants. Antiserum raised against the parent strain was repeatedly absorbed with $0.6 \mathrm{~g}$ wet weight of cells of a $\mathrm{Cog}^{-}$mutant until the antiserum failed to agglutinate the $\mathrm{Cog}^{-}$mutant strain. For $3 \mathrm{ml}$ antiserum, this usually required about 10-15 absorptions with $0.6 \mathrm{~g} \mathrm{Cog}^{-}$ mutant cells in each absorption. Mutant-absorbed antiserum was tested for its ability to inhibit coaggregation between the parent actinomyces strain PK2399 and its streptococcal 
partners, strains 34 and C104. The protein concentration of absorbed antiserum was between 6 and $35 \mathrm{mg} \mathrm{ml}^{-1}$.

Blocking of coaggregation with antiserum. Bacterial cell suspensions were adjusted to 160 Klett units (about $5 \times 10^{8}$ cells $\mathrm{ml}^{-1}$ ) in coaggregation buffer. A $50 \mu$ l aliquot of actinomyces cell suspension was mixed with $10 \mu \mathrm{l}$ of undiluted or diluted antiserum (diluted in modified coaggregation buffer containing $100 \mathrm{mM}$ Tris, $\mathrm{pH} 8.0$, and $0.2 \%, \mathrm{w} / \mathrm{v}, \mathrm{BSA}$ ) in a silanized glass tube $(10 \times 75 \mathrm{~mm})$ and incubated for $30 \mathrm{~min}$ at room temperature. These tubes were prepared by coating glass tubes with Sigmacote (Sigma), rinsing three to four times with distilled water, and drying. After adding $50 \mu \mathrm{l}$ streptococcal partner cells and vortexing, the coaggregation was scored. A score of 0 was given when, after mixing of two partners, no change in turbidity could be observed; a maximum score of 4 was given when, after mixing the cells, the coaggregated cells sedimented immediately, leaving a clear supernatant. Controls containing preimmune sera did not agglutinate actinomyces and did not block coaggregations. Also, the modified coaggregation buffer used to dilute the antiserum did not inhibit coaggregation.

It should be noted that coaggregation blocking was determined immediately after adding partner cells to the $30 \mathrm{~min}$ preincubated actinomyces/antiserum mixture. Coaggregations were detectable immediately after partner cell addition and were often enhanced by mixing the vessel contents, whereas agglutination was not detectable until several hours after the initial mixing and was scored without additional mixing. Agglutination was routinely scored after overnight incubation at $4{ }^{\circ} \mathrm{C}$. In each coaggregation-blocking experiment, an agglutination control consisting of the parent strain PK2399 and a non-partner streptococcus, Streptococcus gordonii DL1, was included; no agglutination was detected in any of the coaggregation-blocking experiments.

Surface preparations from actinomyces strains using mild sonication. Cells were grown overnight in 1 litre screw-capped bottles. Cells were harvested and washed three times in PBS $\left(1.7 \mathrm{mM} \quad \mathrm{KH}_{2} \mathrm{PO}_{4}, 5 \mathrm{mM} \quad \mathrm{Na}_{2} \mathrm{HPO}_{4}\right.$ and $0.15 \mathrm{M} \mathrm{NaCl}$, $\mathrm{pH} 7 \cdot 4)$. After a final wash in $20 \mathrm{mM}$ Tris/ $\mathrm{HCl}(\mathrm{pH} 8 \cdot 0)$, cells were resuspended in ice-cold $20 \mathrm{mM}$ Tris $/ \mathrm{HCl}(\mathrm{pH} 8 \cdot 0)$ at a final concentration of $0 \cdot 2-0 \cdot 3 \mathrm{~g}$ wet weight $\mathrm{ml}^{-1}$. In an icebath, a glass tube containing $3 \mathrm{ml}$ cell suspension was exposed to mild ultrasonication with a microdisruptor KT40 (maximum power is $50 \mathrm{~W}$; Kontes) for two 1 min periods. No cell breakage was observed by microscopic examination of the sonicated cells. All subsequent procedures were done at $4{ }^{\circ} \mathrm{C}$. The sonicated cells were pelleted by centrifugation for $20 \mathrm{~min}$ at $27000 \mathrm{~g}$. The supernatant was centrifuged two additional times at $35000 \mathrm{~g}$ for $40 \mathrm{~min}$ and then filtered through a low protein binding filter $(0 \cdot 22 \mu \mathrm{m}$ pore diameter; Millipore). The protein concentration of the supernatant fluids was determined by the Micro-Bradford assay (Bio-Rad) using bovine serum albumin as standard. A typical protein concentration of the sonicated surface preparations was $0.3-0.6 \mathrm{mg} \mathrm{ml}^{-1}$.

SDSPAGE and immunoblotting. The actinomyces surface preparations were boiled three times for $5 \mathrm{~min}$ under reducing conditions $(10 \%, \mathrm{v} / \mathrm{v}, \beta$-mercaptoethanol) in SDS-PAGE loading buffer $(0 \cdot 125 \mathrm{M}$ Tris $/ \mathrm{HCl}, \mathrm{pH} 6 \cdot 8 ; 4 \%, \mathrm{w} / \mathrm{v}$, SDS; $20 \%, \mathrm{v} / \mathrm{v}$, glycerol; $0.004 \%, \mathrm{w} / \mathrm{v}$, bromphenol blue) (Laemmli, 1970). A sample of usually $5 \mu \mathrm{g}$ protein per lane was separated on precast 4-20\% Tris/glycine gels (Novex). Separated proteins were stained with the ISS Pro-Blue staining kit (Integrated Separation Systems). For immunoblots, the gels were blotted (Towbin et al., 1979) onto nitrocellulose paper (no. 00770, 0.20 $\mu \mathrm{m}$ pore size; Schleicher \& Schuell) in a MiniProtean II Transfer Apparatus (Bio-Rad) or Western Transfer
Apparatus (Novex) in buffer containing $134.4 \mathrm{mM}$ glycine, $17.5 \mathrm{mM}$ Tris/base and $20 \%(\mathrm{v} / \mathrm{v})$ methanol. The molecular masses of actinomyces proteins were determined by comparing the distance migrated with prestained molecular mass standards (Bio-Rad): phosphorylase A, $106 \mathrm{kDa}$; bovine serum albumin, $80 \mathrm{kDa}$; ovalbumin $49.5 \mathrm{kDa}$, carbonic anhydrase, $32.5 \mathrm{kDa}$; soybean trypsin inhibitor, $27.5 \mathrm{kDa}$; and lysozyme, $18.5 \mathrm{kDa}$. Proteins blotted to nitrocellulose were incubated with IgG of rabbit antiserum R59 against type 1 fimbriae of $A$. naeslundii $\mathrm{T} 14 \mathrm{~V}$ or with antiserum $\mathrm{R} 55$ against type 2 fimbriae of $A$. naeslundii $\mathrm{T} 14 \mathrm{~V}$ or with $\mathrm{Cog}^{-}$-mutantabsorbed rabbit antiserum against either parent Actinomyces serovar WVA963 strain PK2399 or against surface sonicates of the parent strain bound to lactose-agarose beads (1:300-1:1000 dilution containing between 10 and $35 \mu \mathrm{g}$ protein $\left.\mathrm{ml}^{-1}\right)$. Bands were visualized by a goat anti-rabbit IgG alkaline phosphatase conjugate (Bio-R ad). Immune complexes were visualized with alkaline-phosphatase-conjugated antirabbit IgG (Bio-Rad) and a dye indicator system supplied by Promega.

Adsorption of actinomyces surface sonicates to lactoseagarose beads. The adsorption of mild sonicates of actinomyces cells to lactose-agarose affinity beads was slightly modified from the method of Hughes et al. (1992). Surface sonicates were obtained by using cells $(12-22 \mathrm{~g}$ wet wt) from 8 to 161 culture medium. After a final wash in $20 \mathrm{mM}$ Tris $/ \mathrm{HCl}$ (pH 8.0), cells were resuspended in $20 \mathrm{mM}$ Tris $/ \mathrm{HCl}(\mathrm{pH} 8 \cdot 0)$ to a final concentration of $0.5-0.7 \mathrm{~g}$ cells wet weight $\mathrm{ml}^{-1}$ in the presence of $1 \mathrm{mM}$ 4-(2-aminoethyl)benzenesulfonyl fluoride hydrochloride and $50 \mathrm{mM}$ iodoacetic acid. Aliquots of about $15 \mathrm{ml}$ cell suspension were placed in an ice-bath and exposed twice for $1 \mathrm{~min}$ to mild ultrasonication as described above. A typical protein concentration of a sonic surface preparation was in the range of $2-4 \mathrm{mg} \mathrm{ml}^{-1}$.

After addition of $0.02 \%(\mathrm{w} / \mathrm{v})$ sodium azide and $1 \mathrm{mM} \mathrm{CaCl}_{2}$, the supernatant was mixed with $1.5 \mathrm{ml}$ prewashed (two washes with $10 \mathrm{ml} 20 \mathrm{mM}$ Tris/ $\mathrm{HCl}, \mathrm{pH} 8 \cdot 0$ ) lactose-agarose beads (Sigma) in a polypropylene tube. The surface sonicate/ bead mixture was rotated end-over-end overnight at $4{ }^{\circ} \mathrm{C}$. The lactose-agarose beads were washed six times with adsorption buffer $\left(20 \mathrm{mM}\right.$ Tris $/ \mathrm{HCl}, \mathrm{pH} 8.0 ; 1 \mathrm{mM} \mathrm{CaCl}_{2} ; 0.02 \%$, w/v, sodium azide). Bound proteins were eluted by incubation with 2-4 ml $100 \mathrm{mM}$ lactose in $20 \mathrm{mM}$ Tris/ $\mathrm{HCl}$ (pH 8.0), $2 \mathrm{mM}$ EDTA and $0.02 \%(\mathrm{w} / \mathrm{v})$ sodium azide for $6 \mathrm{~h}$ at $4{ }^{\circ} \mathrm{C}$. The final wash prior to the lactose elution as well as the material eluted with lactose were dialysed overnight against $20 \mathrm{mM}$ Tris $/ \mathrm{HCl}(\mathrm{pH} 8.0), 2 \mathrm{mM}$ EDTA and $0.02 \%$ (w/v) $\mathrm{NaN}_{3}$. The dialysed samples were concentrated from $2 \mathrm{ml}$ to about $50 \mu \mathrm{l}$ in Centricon-10 centrifugal concentrators (Amicon). These concentrated samples were very dilute and had protein concentrations in the background range of the Micro-Bradford assay (less than $2 \mu \mathrm{g} \mathrm{ml}^{-1}$ ). In control experiments, surface sonicates were adsorbed to mannose-agarose beads (Sigma) which were chemically prepared by the manufacturer in the same way and treated here in an identical manner to the lactose-agarose beads.

Adsorption of surface sonicates to streptococcal partner cells. Cells from a 31 culture of Streptococcus oralis $34(4.5 \mathrm{~g}$ wet wt) were harvested by centrifugation and washed three times in PBS and finally with $20 \mathrm{mM}$ Tris/ $\mathrm{HCl}$ (pH 8.0). Surface sonicate obtained from $12 \mathrm{~g}$ wet weight of actinomyces cells was suspended in about $25-30 \mathrm{ml}$ adsorption buffer and was incubated overnight with $4.5 \mathrm{~g}$ streptococcal partner cells by rotating end-over-end in the presence of protease inhibitors. Cells were subjected to five cycles of washing with adsorption buffer and centrifugation for $10 \mathrm{~min}$ at $10000 \mathrm{~g}$. Proteins were 
eluted from the streptococcal cells by incubation with $5 \mathrm{ml}$ $100 \mathrm{mM}$ lactose in $20 \mathrm{mM}$ Tris $/ \mathrm{HCl}, 2 \mathrm{mM}$ EDTA and $0.02 \%$ $(\mathrm{w} / \mathrm{v}) \mathrm{NaN}_{3}$ for $6 \mathrm{~h}$. The lactose eluate was dialysed, concentrated by ultrafiltration with a Centricon-10 unit as described above and analysed by an SDS-PAGE/immunoblot procedure. The protein concentration of the concentrated washes was at background level (less than $2 \mu \mathrm{g} \mathrm{ml}^{-1}$ ) of the Micro-Bradford assay (Bio-Rad).

Antiserum against actinomyces surface components bound to lactose-agarose affinity beads. The surface sonicate obtained from $20 \mathrm{~g}$ wet weight cells (16 l culture) of strain PK2399 was filtered through a low protein binding filter $(0.22 \mu \mathrm{m}$ pore diameter; Millipore) and adsorbed to $1 \mathrm{ml}$ lactose-agarose beads as described above. After overnight adsorption, the lactose-agarose beads were washed six times with adsorption buffer without sodium azide and kept frozen in $0.5 \mathrm{ml}$ aliquots. A $0.5 \mathrm{ml}$ aliquot of the agarose beads was mixed with Freund's complete adjuvant and injected subcutaneously into a New Zealand White rabbit on day zero. Boost injections were performed every 3 weeks using $0.5 \mathrm{ml}$ beads without addition of Freund's adjuvant. Test and production sera were taken every $21 \mathrm{~d}$ until exsanguination on day 120 . Antisera were tested for their ability to agglutinate strain PK2399 and to block coaggregation between strain PK2399 and S. oralis strains 34 and C104.

\section{RESULTS}

\section{Selection of $\mathrm{Cog}^{-}$mutants of Actinomyces serovar WVA963 strain PK1259}

Spontaneous mutants of the double-antibiotic-resistant strain PK2399 that failed to coaggregate with the streptococcal partners of the parent and wild-type strains were selected. Of the reference strains from the six streptococcal coaggregation groups (Table 1), only those representing groups 3,4 and 5 coaggregated with wild-type PK1259 and parent strain PK2399, and these interactions were lactose-inhibitable (Table 2). With the intent of obtaining different kinds of $\mathrm{Cog}^{-}$mutants, two different selections for $\mathrm{Cog}^{-}$mutants were carried out by using two streptococcal strains representing coaggregation group 3 . The two strains $S$. oralis 34 and C104 representing streptococcal coaggregation group 3 were chosen as partners. From these two selections, a total of $35 \mathrm{Cog}^{-}$mutants was obtained. All mutants failed to coaggregate with all streptococcal reference strains; however, all still interacted with Fusobacterium nucleatum PK1594 (Table 2). Five $\mathrm{Cog}^{-}$mutants, represented by strain PK2407, also did not coaggregate with Veillonella atypica PK1910. The other 30 mutants represented by strains PK2415 and PK3092 still coaggregated with $V$. atypica PK1910. Five mutants represented by PK2407 and an additional five mutants represented by PK2415 were selected with $S$. oralis $\mathrm{C} 104$; the other 25 mutants represented by PK3092 were selected with S. oralis 34 .

\section{Electron microscopy of surface structures}

Electron microscopic examination of the wild-type PK1259 revealed peritrichous fimbriae on the cell surface (Fig. 1). The parent and all $\mathrm{Cog}^{-}$mutant cells appeared morphologically identical in shape and fimbrial structures (data not shown) to those found on the wild-type. The fimbriae appeared as flexible structures of varying length with an overall mean diameter of $3.30 \mathrm{~nm}$ $( \pm 0.05 \mathrm{~nm})$. Each population examined was composed of cells with different densities of fimbriation, with some cells carrying densely distributed fimbriae or more sparsely distributed fimbriae. No clear substructure was visible at higher magnifications. It was not possible to distinguish two structural types of fimbriae on any of the cell types examined. There was no correlation of fimbrial size, length, width or number per cell with coaggregation phenotype.

Table 2. Intergeneric coaggregation of Actinomyces serovar WVA963 strains with several streptococci, $V$. atypica PK1910 and F. nucleatum PK1594

The method for assigning coaggregation scores has been described by Kolenbrander \& Andersen (1990). A score of 4 is the maximum. Scores printed in bold indicate coaggregations that are reversed by adding lactose ( $60 \mathrm{mM}$ final concentration). Coaggregation groups are in parentheses.

\begin{tabular}{|c|c|c|c|c|c|c|c|c|c|}
\hline \multirow{3}{*}{$\begin{array}{l}\text { Actinomyces serovar WVA963 } \\
\text { strains }\end{array}$} & \multicolumn{9}{|c|}{ Coaggregation score } \\
\hline & \multicolumn{7}{|c|}{ Streptococcal coaggregation group reference strain } & \multirow[t]{2}{*}{ PK1910* } & \multirow[t]{2}{*}{ PK1594† } \\
\hline & $\begin{array}{c}\text { DL1 } \\
(1)\end{array}$ & $\begin{array}{l}\mathrm{H} 1 \\
(2)\end{array}$ & $\begin{array}{l}34 \\
(3)\end{array}$ & $\begin{array}{c}\text { C104 } \\
(3)\end{array}$ & $\begin{array}{l}\mathrm{J} 22 \\
(4)\end{array}$ & $\begin{array}{c}\text { PK509 } \\
(5)\end{array}$ & $\begin{array}{l}\text { PK488 } \\
\quad(6)\end{array}$ & & \\
\hline PK1259 (wild-type) & 0 & 0 & 4 & 4 & 4 & 3 & 0 & 3 & 3 \\
\hline PK2399 & 0 & 0 & 4 & 4 & 4 & 3 & 0 & 3 & 3 \\
\hline PK2407 ( $\mathrm{Cog}^{-}$mutant) type $2^{-}$ & 0 & 0 & 0 & 0 & 0 & 0 & 0 & 0 & 3 \\
\hline PK2415 ( $\mathrm{Cog}^{-}$mutant) type $2^{+}$ & 0 & 0 & 0 & 0 & 0 & 0 & 0 & 3 & 3 \\
\hline PK3092 (Cog ${ }^{-}$mutant) type $2^{+}$ & 0 & 0 & 0 & 0 & 0 & 0 & 0 & 3 & 3 \\
\hline
\end{tabular}

*Veillonella atypica PK1910.

†F. nucleatum PK1594. 


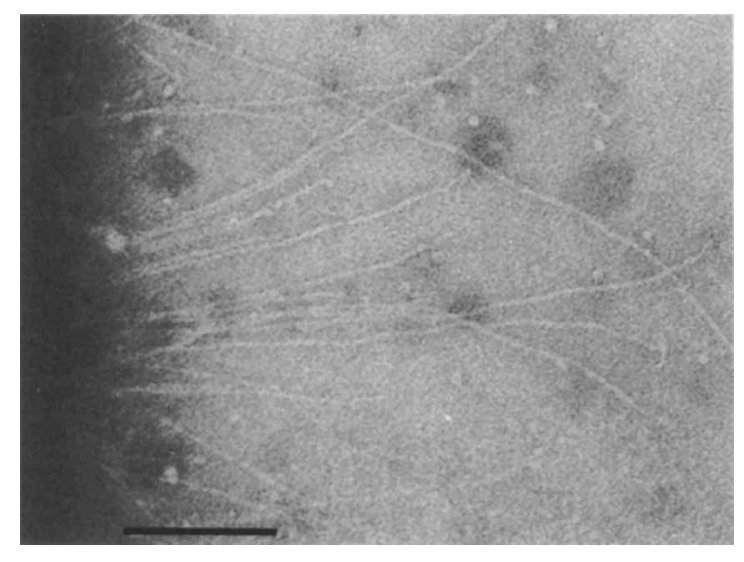

Fig. 1. Electron micrograph of fimbriae of Actinomyces serovar WVA963 wild-type PK1259 negatively stained with $1 \%$ methylamine tungstate. The actinomyces cell is just visible at the left edge of the micrograph. Bar, $100 \mathrm{~nm}$.

Table 3. Agglutination of parent and $\mathrm{Cog}^{-}$strains of Actinomyces serovar WVA963 with IgG against fimbriae of $A$. naes/undii T14V

Values are the lowest protein concentration $\left(\mu \mathrm{g} \mathrm{m}^{-1}\right)$ to cause agglutination of bacterial cells.

\begin{tabular}{|lcc|}
\hline \multirow{2}{*}{ Strain } & \multicolumn{2}{c|}{ Antibody } \\
\cline { 2 - 3 } & Anti-type 1* & Anti-type $2 \dagger$ \\
\hline PK1259 & 12 & $6 \cdot 2$ \\
PK2399 & $6 \cdot 2$ & $6 \cdot 2$ \\
PK2407 & $3 \cdot 1$ & $>100 \neq$ \\
PK2415 & $3 \cdot 1$ & $6 \cdot 2$ \\
PK3092 & $3 \cdot 1$ & $6 \cdot 2$ \\
T14V & $0 \cdot 11$ & $0 \cdot 2$ \\
\hline
\end{tabular}

*Immune rabbit IgG (R59) directed against type 1 fimbriae (Cisar et al., 1988).

† Immune rabbit IgG (R55) directed against type 2 fimbriae (Cisar et al., 1988).

$\ddagger$ Highest concentration tested $\left(100 \mu \mathrm{g} \mathrm{ml}^{-1}\right)$ did not show any agglutination.

\section{Functional characterization of fimbriae}

The ability of actinomyces cells to bind to PRP-coated latex beads was evaluated. All tested strains, wild-type strain PK1259, parent strain PK2399 and $\mathrm{Cog}^{-}$mutant strains PK2407, PK2415 and PK3092, agglutinated with PRP-coated latex beads in a manner indistinguishable from the control strain A. naeslundii T14V. There was no agglutination with latex beads coated with bovine serum albumin.

Further, the agglutination of parent and mutant strains of Actinomyces serovar WVA963 was tested with IgG against type 1 and type 2 fimbriae of $A$. naeslundii T14V. All strains tested (Table 3) agglutinated with R59 IgG

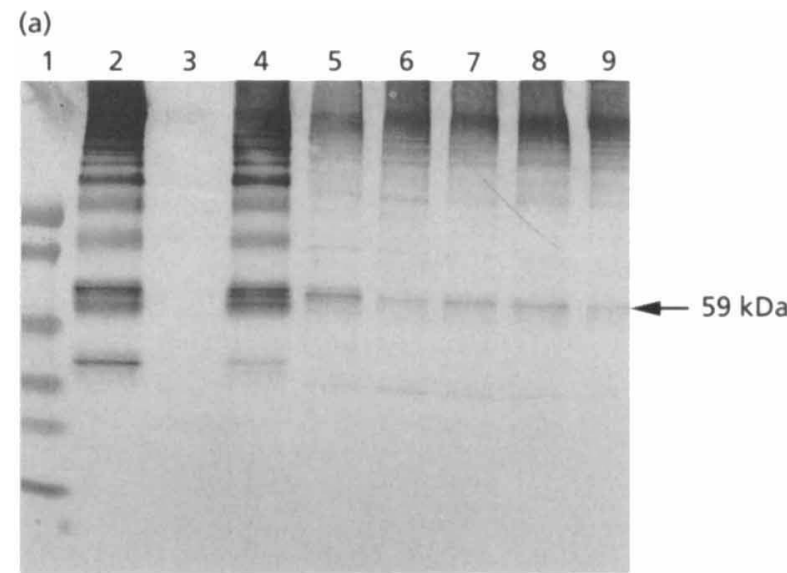

(b)

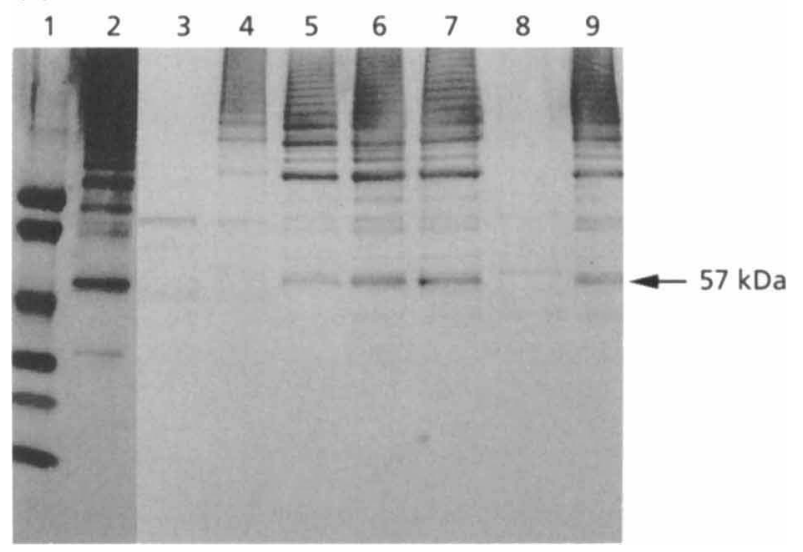

Fig. 2. Immunoblots of surface proteins of wild-type and mutant strains of Actinomyces serovar WVA963 and $A$. naes/undii T14V. Proteins were separated by $4-20 \%$ Tris/glycine SDS-PAGE, transblotted and incubated with either (a) anti-type $1\left(5.5 \mu \mathrm{g}\right.$ protein $\left.\mathrm{ml}^{-1}\right)$ or (b) anti-type $2\left(0.85 \mu \mathrm{g}\right.$ protein $\mathrm{ml}^{-1}$ to develop lane 2 and $5.0 \mu \mathrm{g}$ protein $\mathrm{ml}^{-1}$ to develop lanes 3-9) IgG serum made against fimbriae purified from $A$. naeslundii $\mathrm{T14V}$. The amount of protein loaded per lane in (a) was $5 \mu \mathrm{g}$ in lanes $2-4$ and $10 \mu \mathrm{g}$ in lanes 5-9. The amount loaded in (b) was $2.5 \mu \mathrm{g}$ in lane $2,5 \mu \mathrm{g}$ in lanes 3 and 4 , and $9 \mu \mathrm{g}$ in lanes $5-9$. Lane 1 contains the prestained molecular mass standards (molecular masses are 106, 80, 49.5, 32.5, 27.5 and $18.5 \mathrm{kDa}$ ). $A$. naes/undii T14V strains: lane 2 , wild-type T14V (type $1^{+}$, type $2^{+}$); lane 3, mutant 147 (type $1^{-}$, type $2^{-}$); and lane 4, mutant 5519 (type $1^{+}$, type $2^{-}$). Actinomyces serovar WVA963 strains: lane 5, parent PK2399; lane 6, Cog $^{-}$mutant PK3092; lane 7 , $\mathrm{Cog}^{-}$mutant PK2415; lane 8, $\mathrm{Cog}^{-}$mutant PK2407; lane 9, wild-type PK1259.

against type 1 fimbriae of $A$. naeslundii $\mathrm{T} 14 \mathrm{~V}$, indicating the presence of type 1 fimbriae on these strains. Type 2 fimbriae were detected on all strains except the $\mathrm{Cog}^{-}$ strain PK2407. In comparison to the control strain $A$. naeslundii $\mathrm{T} 14 \mathrm{~V}$, a 30 -fold higher IgG concentration was generally necessary to observe agglutination of the Actinomyces serovar WVA963 strains (Table 3). However, even at the highest concentration tested $\left(100 \mu \mathrm{g} \mathrm{ml}^{-1}\right)$, anti-type $2 \mathrm{IgG}$ did not agglutinate cells of the $\mathrm{Cog}^{-}$mutant PK2407, indicating the absence of type 2 fimbriae on this strain. 


\section{Table 4. Blocking of coaggregation by $\mathrm{Cog}^{-}$mutant absorbed anti-PK2399 serum}

The absorbed antisera were against parent PK2399 and absorbed with $\mathrm{Cog}^{-}$mutant PK3092 (absorbed antiserum A-3092) or Cog mutant PK2407 (absorbed antiserum A-2407). The strains listed are coaggregation partner strains of Actinomyces serovar WVA963 strain PK2399. - , Complete blocking, coaggregation score of $0 ; \pm$, partial blocking, coaggregation score of 1 or $2 ;++$, no blocking, maximum coaggregation score of 3 or 4 . ND, Not done.

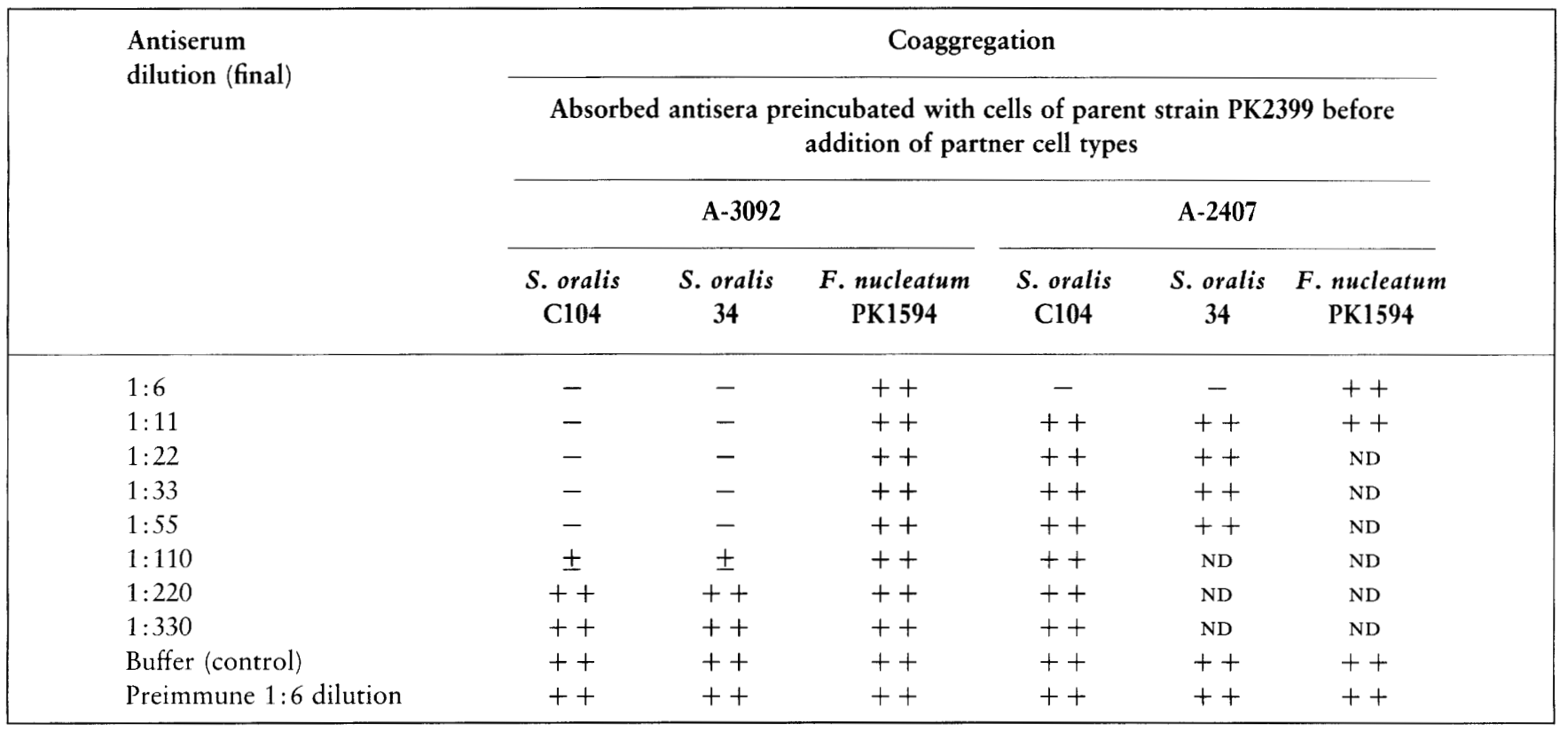

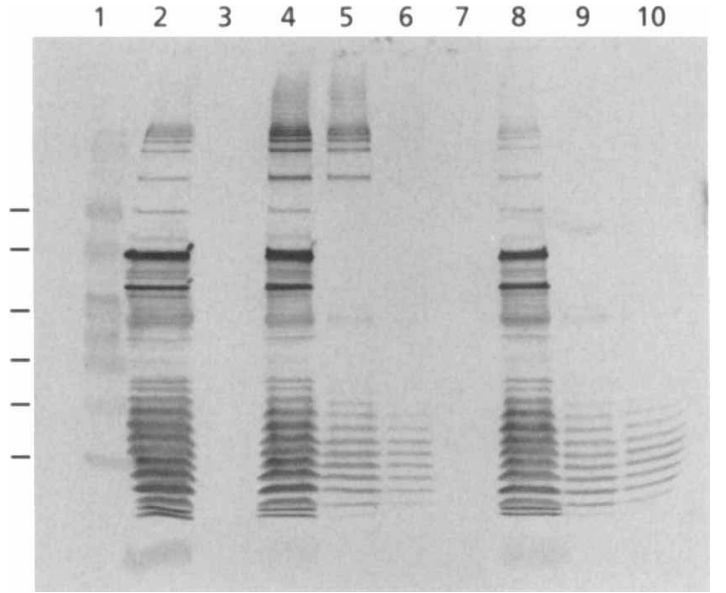

Fig. 3. Comparison of the binding of parent strain surface sonicate to lactose-agarose and mannose-agarose beads. This immunoblot was developed with antiserum A-3092 (see legend to Table 4). Lanes: 1, prestained molecular mass standards (106, $80,49.5,32.5,27.5$ and $18.5 \mathrm{kDa}$ indicated by line ticks on the left); $2,5 \mu \mathrm{g}$ surface sonicate of parent strain PK2399; 3, boiled lactose-agarose beads prior to adsorption of surface sonicate; 4 , boiled lactose-agarose beads after the first wash with adsorption buffer; 5, boiled lactose-agarose beads after six washes with adsorption buffer; 6 , boiled lactose-agarose beads after two elutions of bound proteins with $100 \mathrm{mM}$ lactose in each elution buffer; 7, boiled mannose-agarose beads prior to adsorption of surface sonicate; $\mathbf{8}$, boiled mannose-agarose beads after the first wash with adsorption buffer; 9, boiled mannose-agarose beads after six washes with adsorption buffer; 10, boiled mannose-agarose beads after two elutions with $100 \mathrm{mM}$ lactose.
Immunological characterization of type 1 and type $\mathbf{2}$ fimbriae of Actinomyces serovar WVA963 strain PK1259

To investigate the relationship of these putative fimbrial subunits with the subunits of type 1 and type 2 fimbriae of A. naeslundii strains T14V (type $1^{+}$, type $2^{+}$), 5519 (type $1^{+}$, type $2^{-}$) and 147 (type $1^{-}$, type $2^{-}$), surface preparations were made, the proteins were separated by SDS-PAGE, and the type 1 and type 2 subunits were identified on immunoblots by their reactions with R59 anti-type 1 and R55 anti-type 2 sera, respectively (Fig. 2). Anti-type 1 sera reacted strongly with a band of about $59 \mathrm{kDa}$ in the parent strain T14V (Fig. 2a, lane 2) and strain 5519 (Fig. 2a, lane 4). This band was absent in the type 1 negative strain 147 (Fig. 2a, lane 3). Also absent in lane 3 were immunoreactive proteins of higher molecular size. For comparison, all five of the Actinomyces serovar WVA963 strains (Fig. 2a, lanes 5-9) produced type 1 immunoreactive proteins at $59 \mathrm{kDa}$, and all synthesized high molecular size immunoreactive proteins, indicating the presence of type 1 homologous fimbriae on these strains (Cisar et al., 1991; Yeung et al., 1987). As expected, the band at $59 \mathrm{kDa}$ reacted much more weakly than with the $A$. naeslundii strains, since a 30 -fold higher concentration of anti-type 1 serum was needed to agglutinate these strains as compared to the homologous $A$. naeslundii T14V strains (Table 3).

Likewise, surface preparations of the reference strains were reacted with anti-type 2 serum (Fig. 2b). A strongly staining band at about $57 \mathrm{kDa}$ was evident in strain 
T14V (Fig. 2b, lane 2), as well as numerous high molecular size proteins, as has been reported by Donkersloot et al. (1985) and Yeung \& Cisar (1988). Neither of the reference type $2^{-}$mutants (Fig. 2b, lanes 3 and 4) produced the $57 \mathrm{kDa}$ protein. Since the antitype 2 serum reacted about 30 -fold more strongly with A. naeslundii $\mathrm{T} 14 \mathrm{~V}$ than with the Actinomyces serovar WVA963 strains (Table 3), a fourfold higher protein concentration of the latter strains was applied to the gel in order to detect immunoreactive proteins. Four of the Actinomyces WVA963 strains (Fig. 2b, lanes 5, 6,7 and 9) possessed an immunoreactive protein at $57 \mathrm{kDa}$, but $\mathrm{Cog}^{-}$mutant PK2407 did not synthesize this protein (Fig. 2b, lane 8), and it did not produce any high molecular size type 2 immunoreactive proteins (Fig. 2b, upper portion of lane 8).

\section{Characterization of antiserum raised against whole cells of parent Actinomyces serovar WVA963 strain PK2399}

Agglutination of whole cells of PK2399 by the polyclonal anti-PK2399 serum indicated a titre of 1:13000. Two aliquots of the antiserum were absorbed, respectively, with either $\mathrm{Cog}^{-}$strain PK3092 (class I) or $\mathrm{Cog}^{-}$strain PK2407 (class II). Strain PK3092 synthesized type 2 actinomyces fimbriae, but strain PK2407 lacked these fimbriae. Anti-PK2399 serum absorbed with PK3092 (A3092) agglutinated the parent at a 1:1024 dilution of antiserum but did not agglutinate class II mutant cells. However, anti-PK2399 serum absorbed with PK2407 (A-2407) agglutinated the parent and $\mathrm{Cog}^{-}$strain PK3092 at a 1:1024 dilution of antiserum but not PK2407 at any dilution. These results suggested that the surface epitopes of class II mutant strain PK2407 were different from the class I mutant strain PK3092 and parent strain PK2399.

Anti-PK2399 serum absorbed with the parent strain PK2399 failed to block coaggregation of PK2399 and its streptococcal partners. PK3092-absorbed anti-PK2399 serum (A-3092) completely blocked the coaggregation between the parent strain PK2399 and its streptococcal partners at a 1:55 dilution (Table 4). PK2407-absorbed anti-PK2399 serum (A-2407) showed about a 10-fold weaker ability to block coaggregation. None of the absorbed antisera blocked coaggregation between the parent strain PK2399 and F. nucleatum PK1594, suggesting that the blocking of the streptococcalactinomyces coaggregations was due to specific antibody recognition of lactose-binding molecules on the actinomyces surface.

\section{Lactose-agarose beads as affinity matrix for enrichment of lactose-binding proteins in surface sonicates}

Lactose-agarose beads were used as an affinity matrix to enrich for lactose-binding proteins released by mild sonication of actinomyces cells. To exclude nonspecific interactions between actinomyces surface components and the agarose beads, mannose-agarose beads were chosen as a control matrix, since mannose did not inhibit coaggregation. A surface sonicate of the parent strain PK2399 (Fig. 3, lane 2) was adsorbed to either lactose-agarose beads or mannose-agarose beads. Proteins released by boiling from both lactose-agarose (Fig. 3, lanes 3-6) and mannose-agarose beads (Fig. 3, lanes 7-10) during several steps after the adsorption of the surface preparation were detected by an immunoblot using absorbed serum A-3092.

Neither lactose-agarose beads (Fig. 3, lane 3) nor mannose-agarose beads (Fig. 3, lane 7) showed any immunoreactive bands before mixing with the surface preparation. After mixing the lactose-agarose beads with the surface preparation and one wash with buffer, the lactose-agarose beads showed an enrichment of high molecular mass material (above the highest molecular mass standard at $106 \mathrm{kDa}$ ) (Fig. 3, lane 4), but the mannose-agarose beads (Fig. 3, lane 8) showed no enrichment compared to the starting surface sonicate (Fig. 3, lane 2). Comparison of the surface sonicate (Fig. 3 , lane 2) with proteins remaining bound to six-timeswashed lactose-agarose beads and released by boiling revealed a considerable enrichment of high molecular mass proteins (above $106 \mathrm{kDa}$ ) and a decrease in all other immunoreactive proteins (Fig. 3, lane 5). Further, these high molecular size proteins could be eluted by incubating the lactose-agarose beads with $100 \mathrm{mM}$ lactose for $6 \mathrm{~h}$ at $4{ }^{\circ} \mathrm{C}$ as shown by their absence in boiled beads after lactose elution (Fig. 3, lane 6). In contrast, the mannose-agarose beads did not retain high molecular mass proteins from the surface sonicates (Fig. 3 , lane 9). Washing the mannose-agarose beads with $100 \mathrm{mM}$ lactose did not remove any additional proteins from the mannose-agarose beads (Fig. 3, lane 10), suggesting that the faster migrating ladder of bands (perhaps lipoteichoic acid) were bound to agarose beads non-specifically. Thus, lactose-agarose beads specifically enriched high molecular mass actinomyces surface proteins.

\section{SDSPAGE and immunoblot analysis of actinomyces surface proteins from parent and $\mathrm{Cog}^{-}$mutant strains enriched by lactose-agarose beads}

Freshly harvested cells from $8 \mathrm{I}$ culture medium (about $10 \mathrm{~g}$ cells wet $\mathrm{wt}$ ) were used to affinity-purify lactosebinding surface proteins. The routine lactose-agarose bead enrichment analysis of the parent included Problue (Fig. 4a, lanes 1-5) and/or silver staining (Fig. 4a, lanes 6 and 7) of SDS-PAGE of surface sonicates (Fig. 4a, lane 2), the first buffer wash (Fig. 4a, lane 3), a concentrated sixth buffer wash (Fig. 4a, lanes 4 and 6; one half of entire concentrated sample loaded onto gel), and a concentrated $100 \mathrm{mM}$ lactose elution (Fig. 4a, lanes 5 and 7 ; one-quarter of entire sample from original 81 culture loaded onto gel). Little or no difference was observed between the starting surface sonicate preparation and the first buffer wash, which probably reflected trapped surface proteins in the bead matrix. After six washes, very little protein was detectable by Pro-blue staining (Fig. 4a, lane 4). Some high molecular 
(a)

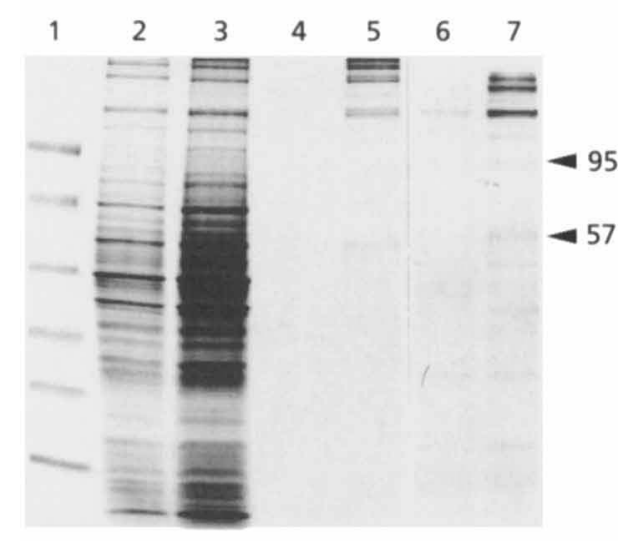

(b)

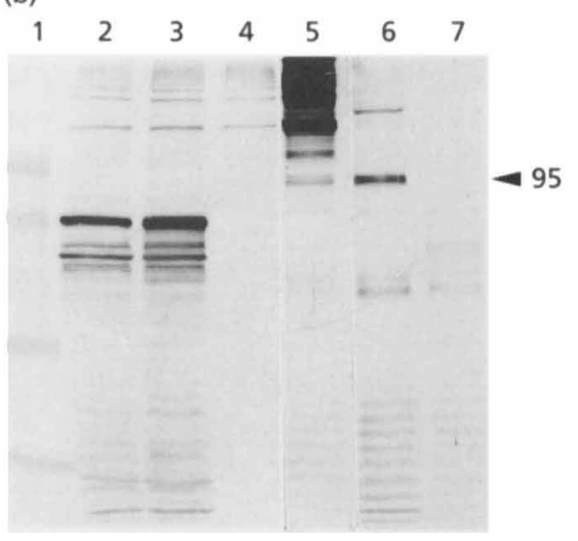

Fig. 4. Comparison of actinomyces proteins eluted from lactose-agarose beads by $100 \mathrm{mM}$ lactose. (a) Protein stain of surface sonicate of the parent strain PK2399 adsorbed to lactose-agarose beads. Lanes 2-5 were stained with Pro-blue; lanes 6 and 7 were silver stained. Lanes: 1, prestained molecular mass standards $(106,80,49.5,32.5,27.5$ and $18.5 \mathrm{kDa}) ; 2,5 \mu \mathrm{g}$ surface sonicate of parent strain PK2399; 3, $5 \mu \mathrm{g}$ protein released with the first adsorption buffer wash; 4 and 6 , protein released into buffer after six washes with adsorption buffer and concentrated 40-fold; 5 and 7 , protein eluted with $100 \mathrm{mM}$ lactose and concentrated 40 -fold. Arrowheads indicate the positions of 57 and $95 \mathrm{kDa}$ proteins. (b) Immunoblot of surface sonicates of the parent and $\mathrm{Cog}^{-}$mutant strains released from lactose-agarose beads by eluting with $100 \mathrm{mM}$ lactose. The immunoblot was incubated with A-3092 (see legend to Table 4). Lanes 1-5 were loaded with identical samples of the parent strain PK2399 as listed in Fig. 4(a). Lane 6, 40-fold concentrated surface sonicate proteins of class II $\mathrm{Cog}^{-}$mutant PK2407 eluted from lactose-agarose beads with $100 \mathrm{mM}$ lactose. Lane 7, 40fold concentrated surface sonicate proteins of class I $\mathrm{Cog}^{-}$ mutant strain PK3092 eluted with $100 \mathrm{mM}$ lactose. The arrowhead indicates the position of the $95 \mathrm{kDa}$ protein.

mass proteins, greater than $106 \mathrm{kDa}$, and some low molecular mass peptides, less than $30 \mathrm{kDa}$, were faintly visible by silver staining (Fig. 4a, lane 6). The concentrated lactose-released proteins (Fig. 4a, lanes 5 and 7), however, revealed bands that were readily detectable with Pro-blue (Fig. 4a, lane 5) in the high molecular mass range (greater than $106 \mathrm{kDa}$ ) (and a detectable band at $57 \mathrm{kDa}$ ). The silver-stained lane (Fig. 4a, lane 7) of a different experiment showed an additional band with a molecular mass of $95 \mathrm{kDa}$.

The immunoblot (Fig. 4b, lanes 2-5) of an identical gel of parent strain samples (Fig. $4 \mathrm{a}$, lanes $2-5$ ) as well as the concentrated lactose-released proteins from the two classes of $\mathrm{Cog}^{-}$mutant surface sonicates (Fig. 4b, lanes 6 and 7) was developed with absorbed serum A-3092. The results showed the adsorption and elution of lactose-binding proteins from the lactose-agarose beads (Fig. 4b, lanes 2-5). The PK2399 eluate (Fig. 4b, lane 5) contained a $95 \mathrm{kDa}$ protein as well as higher molecular mass proteins. The higher molecular sizes may be composed of fimbriae-adhesin polymers of various lengths. Interestingly, the $95 \mathrm{kDa}$ band could also be seen in the concentrated lactose elution of the class II $\mathrm{Cog}^{-}$mutant strain PK2407 (Fig. 4b, lane 6), which was lacking the $57 \mathrm{kDa}$ type 2 fimbrial monomer (see Fig. 2b, lane 8 ). Only one additional higher molecular size band of approximately twice the size of the $95 \mathrm{kDa}$ protein was observed (Fig. 4b, lane 6). The concentrated lactose wash of the class I Cog ${ }^{-}$mutant PK3092 (Fig. 4b, lane 7) did not reveal any protein bands of $95 \mathrm{kDa}$ or larger size. Since the PK3092-absorbed antiserum (A-3092) used in this immunoblot blocked coaggregation (Table 4), the $95 \mathrm{kDa}$ protein it recognized might be the adhesin involved in the lactose-inhibitable coaggregations between actinomyces and streptococci. The observation that the $\mathrm{Cog}^{-}$mutant PK2407 bears this $95 \mathrm{kDa}$ putative adhesin agrees with the finding that PK2407 cells removed most of the coaggregation-blocking antibodies from anti-parent serum (Table 4).

\section{Antiserum raised against parent PK2399 surface sonicates adsorbed to lactose-agarose beads}

Parent surface sonicate components that were bound to lactose-agarose beads (Fig. 4b, lane 5) were used to obtain antibodies directed against the putative adhesin and its high molecular size complexes. The antiserum was absorbed with class I mutant PK3092 cells, and, at a dilution of $1: 55$, it completely blocked the parent PK2399 coaggregation with its partner $S$. oralis 34 . Even undiluted antiserum had no effect on the lactosenoninhibitable actinomyces-fusobacteria coaggregation. This antiserum was called L-A-3092, and its coaggregation-blocking ability was the same as that of the A-3092 serum (complete blocking at 1:55 dilution; see Table 4).

\section{SDSPAGE and immunoblot analysis of actinomyces surface proteins enriched by adsorption to $S$. oralis 34 as affinity matrix}

To investigate a possible role in mediating lactoseinhibitable coaggregation with streptococci, preparations enriched for the $95 \mathrm{kDa}$ protein from actinomyces surface sonicates were tested for the ability to adsorb to streptococcal partner cells. Cells of $S$. oralis 34 were mixed with the surface sonicate proteins of $12 \mathrm{~g}$ wet weight of actinomyces cells and rotated end-over-end for $16 \mathrm{~h}$. After washing the streptococcal cells five times 


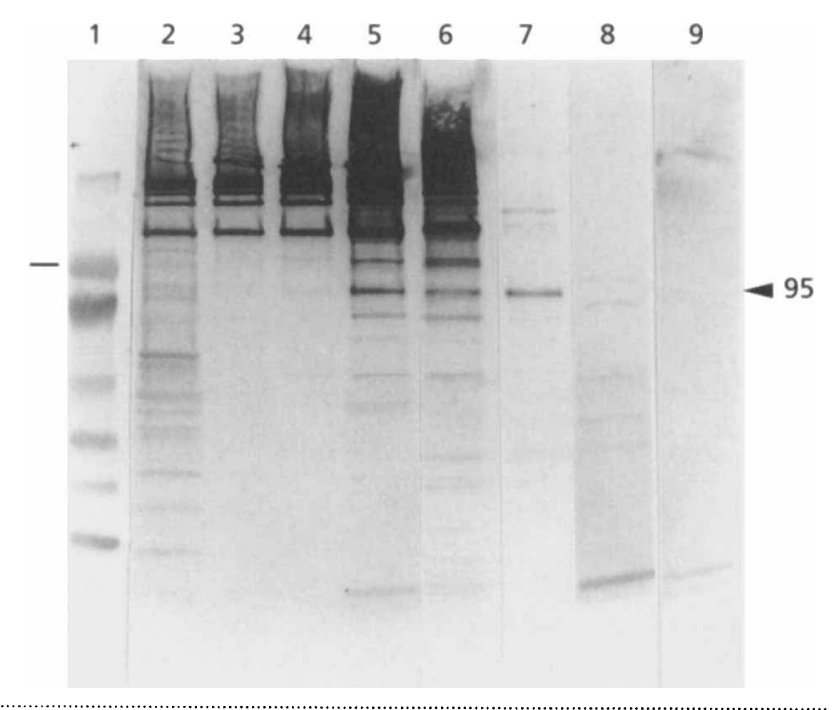

Fig. 5. Comparison of actinomyces proteins bound to streptococcal partner $S$. oralis 34 and eluted with $100 \mathrm{mM}$ lactose. Immunoblot of surface sonicates of Actinomyces serovar WVA963 strains eluted from S. oralis 34 with $100 \mathrm{mM}$ lactose. The immunoblot was incubated with antiserum L-A3092. Lanes: 1, prestained molecular mass standards $(106,80$, $49.5,32.5,27.5$ and $18.5 \mathrm{kDa}$ ) (the pointer to the left indicates the position of the $106 \mathrm{kDa}$ standard); $2,5 \mu \mathrm{g}$ surface sonicate of wild-type strain PK1259; 3, $5 \mu \mathrm{g}$ proteins released with the first adsorption buffer wash; 4, protein released into buffer after five washes with adsorption buffer and concentrated 40 fold; 5, 40-fold concentrated surface sonicate proteins of wildtype strain PK1259 eluted with $100 \mathrm{mM}$ lactose; 6, 40-fold concentrated surface sonicate proteins of parent strain PK2399 eluted with $100 \mathrm{mM}$ lactose; 7, 40-fold concentrated surface sonicate proteins of $\mathrm{Cog}^{-}$mutant PK2407 eluted with $100 \mathrm{mM}$ lactose; 8, 40-fold concentrated surface sonicate proteins of $\mathrm{Cog}^{-}$mutant strain PK3092 eluted with $100 \mathrm{mM}$ lactose; 9, $2 \mu \mathrm{g}$ surface sonicate of $S$. oralis 34 . The arrowhead on the right indicates the position of the $95 \mathrm{kDa}$ band.

with buffer, the bound proteins were eluted with $100 \mathrm{mM}$ lactose. Fig. 5 shows molecular mass standards (Fig. 5, lane 1), surface sonicates of the wild-type strain PK1259 (Fig. 5, lane 2), the first buffer wash (Fig. 5, lane 3 ) and the fifth and final wash before the lactose wash (Fig. 5, lane 4). The immunoblot was developed with LA-3092 serum, which was very immunoreactive with high molecular mass material in surface sonicates (Fig. 5 , lane 2). By comparison, the immunoreactivity of A3092 serum with surface sonicates (see Fig. 3, lane 2 and Fig. 4b, lane 2) is primarily with lower molecular size material (below $80 \mathrm{kDa}$ ). This would be expected for an antiserum raised against putative lactose-sensitive adhesin and adhesin-fimbriae complexes bound to the lactose-agarose beads. Loosely bound high molecular size material was removed from the streptococcal cells by the buffer washes (Fig. 5, lanes 3 and 4).

An enrichment of the $95 \mathrm{kDa}$ putative adhesin was observed with lactose eluates of the wild-type strain PK1259 (Fig. 5, lane 5), parent strain PK2399 (Fig. 5, lane 6) and the $\mathrm{Cog}^{-}$mutant strain PK2407 (Fig. 5, lane 7). Prominent in the lanes of the wild-type and parent was the immunoreactive high molecular size material that was absent in the lane of the $\mathrm{Cog}^{-}$mutant strain PK2407 (Fig. 5, lane 7). Bands of about the size of adhesin dimers were again visible in the lactose eluates from the streptococcal surface (Fig. 5, lane 7) as they were in the lactose eluates from the lactose-agarose beads (see Fig. 4b, lane 6). No immunoreactive material was present in the lactose-released proteins of the class $\mathrm{I} \mathrm{Cog}^{-}$mutant strain PK3092 (Fig. 5, lane 8) or from cells of the streptococcal partner $S$. oralis 34 (Fig. 5, lane 9) that were treated identically with buffer and lactose.

\section{DISCUSSION}

This study was initiated to identify the actinomyces adhesin on Actinomyces serovar WVA963 that mediates lactose-inhibitable coaggregations with streptococcal partners. Actinomyces serovar WVA963 strain PK1259 (wild-type) was chosen since all of its known coaggregations with streptococci are lactose-inhibitable (Kolenbrander et al., 1983; Kolenbrander \& London, 1992). Two classes of spontaneously occurring $\mathrm{Cog}^{-}$ mutants were selected. Mutant strain PK3092 (class I) synthesized type 2 fimbriae, which have been shown to be involved in lactose-inhibitable coaggregations with streptococci (Cisar et al., 1983, 1984), but class II mutants (e.g. PK2407) lacked these fimbriae. Since neither mutant class coaggregated with streptococci, it was assumed that the lactose-sensitive adhesin was absent from these mutants. We have shown here that a $95 \mathrm{kDa}$ protein on the surface of the parent is the putative adhesin that mediates these lactose-inhibitable coaggregations with streptococci. Furthermore, it appears that the class II mutant produced this protein but was unable to present the putative adhesin properly on the cell surface. These results suggest that the putative adhesin is a protein distinct from the type 2 fimbrial subunit which is about $57 \mathrm{kDa}$ in this oral actinomyces.

Antiserum raised against the parent strain and absorbed with the class I mutant PK3092 (A-3092) blocked lactoseinhibitable coaggregation with streptococci but not the noninhibitable coaggregation with fusobacteria, indicating its specificity for lactose-inhibitable coaggregations (Table 4). In contrast, class II mutant PK2407 absorbed antiserum (A-2407) lost nearly all of its blocking ability presumably because of the presence of the putative adhesin on PK2407 (Table 4). Thus, we used the class I mutant absorbed antiserum to identify the putative actinomyces lactose-sensitive adhesin in immunoblots.

Comparison of native surface sonicates of parent and mutants did not reveal any differences by SDS-PAGE or immunoblots incubated with A-3092 serum. However, the putative adhesin was detected in lactose eluates obtained from these surface sonicates after adsorption to lactose-agarose affinity beads. The putative adhesin appeared as a $95 \mathrm{kDa}$ band in the parent (Fig. 4b, lane 5) and class II mutant (Fig. 4b, lane 6) but was absent in the class I mutant (Fig. 4b, lane 7). In addition, the parent strain contained a large amount of high molecular mass material (Fig. 4b, lane 5) which presumably consisted of adhesin-fimbriae complexes of various sizes. This high 
molecular mass material was absent in the class II mutant (Fig. 4b, lane 6), which is consistent with the absence of type 2 fimbriae on this strain. The class II mutant contained a single additional band of higher molecular size which has the size of an adhesin dimer. For comparison, a tetramer of the $75 \mathrm{kDa}$ lactosesensitive adhesin has been reported for the oral strain $P$. loescheii PK1295 (London \& Allen, 1990).

To obtain an antiserum against the putative adhesin, surface sonicate of the parent was adsorbed to lactoseagarose beads and, after extensive washing, was used as the antigen. After adsorption with class I mutant cells, this antiserum (L-A-3092) exhibited the same coaggregation-blocking ability as the mutant-absorbed anti-parent serum (A-3092). This specific blocking of lactose-inhibitable coaggregations indicated its usefulness in identifying the putative lactose-sensitive adhesin. The interaction of surface sonicates with streptococcal partner cells when used as an affinity matrix was investigated with L-A-3092. Immunoblots of lactose eluates revealed a $95 \mathrm{kDa}$ band in wild-type, parent and class II mutant cells, but not in class I mutant cells. Thus, both an artificial specific affinity matrix like lactoseagarose beads and the natural streptococcal surface receptor could bind the $95 \mathrm{kDa}$ lactose-sensitive protein. The bound protein remained adherent through five buffer washes, which suggests that the binding is specific.

It appears that the putative adhesin is present in very small numbers per cell, since $15-20 \mathrm{~g}$ wet weight of actinomyces cells was needed to obtain sufficient surface protein for enrichment by affinity chromatography. The lactose eluate had to be concentrated about 40 -fold and about one-quarter of the concentrate was loaded per lane for SDS-PAGE. In another oral bacterium, $P$. loescheii PK1295, there are only about 400 molecules per cell for its lactose-sensitive adhesin (Weiss et al., 1988) and this same organism presents only 310 molecules of a second adhesin on its cell surface (Weiss et al., 1988). In E. coli, the ratio of 1 adhesin molecule per 1000 pilin subunits for the P pili has been reported (Lindberg et al., 1987). Presumably, adhesins with high affinity for their cognate receptors do not need to be in high numbers per cell to be effective in maintaining the union of the two cell types.

The presence of a biochemically functional adhesin on the cell surface of Actinomyces serovar WVA963 strain PK2407 in the absence of type 2 fimbriae is comparable to the presence of the $P$ pilus adhesin (PapG) on the surface of $E$. coli mutants that lack a P pilus (Lindberg et al., 1987; Uhlin et al., 1985). Also, E. coli mutants producing type 1 adhesin (FimH) in the absence of type 1 pili retain the mannose-sensitive haemagglutination but are unable to bind to epithelial cells (Hultgren $e t$ al., 1990). Recently, an adhesin, PilC, was described for Neisseria gonorrhoeae that is distinct from the pilus subunit PilE of type IV pili in N. gonorrhoeae (Rudel et al., 1995). Likewise, we have identified an adhesin on the class II mutant PK2407 that can remove coaggregationblocking antibodies but cannot mediate coaggregation. The putative adhesin could be released from mutant
PK2407 by mild sonication and bound to streptococcal cells. The lactose-sensitive function relevant to coaggregation was demonstrated by the binding of the $95 \mathrm{kDa}$ putative adhesins of parent and mutant to streptococci and subsequent elution by lactose. Thus, we propose that the $95 \mathrm{kDa}$ putative adhesin is distinct from the $57 \mathrm{kDa}$ type 2 fimbrial subunits. The results also indicate that to mediate coaggregation it must be presented properly on the type 2 fimbriae. Additional support for two distinct proteins comes from our characterization of the class I mutant PK3092, which produces type 2 fimbriae but has no detectable adhesin.

\section{REFERENCES}

Abraham, S. N., Goguen, J. D., Sun, D., Klemm, P. \& Beachey, E. H. (1987). Identification of two ancillary subunits of Escherichia coli type 1 fimbriae by using antibodies against synthetic oligopeptides of fim gene products. J Bacteriol 169, 5530-5535.

Brennan, M. J., Cisar, J. O., Vatter, A. E. \& Sandberg, A. L. (1984). Lectin-dependent attachment of Actinomyces naeslundii to receptors on epithelial cells. Infect Immun 46, 459-464.

Brennan, M. J., Cisar, J. O. \& Sandberg, A. L. (1986). A $160-$ kilodalton epithelial cell surface glycoprotein recognized by plant lectins that inhibit the adherence of Actinomyces naeslundii. Infect Immun 52, 840-845.

Cisar, J. O., Curl, S. H., Kolenbrander, P. E. \& Vatter, A. E. (1983). Specific absence of type 2 fimbriae on a coaggregation-defective mutant of Actinomyces viscosus T14V. Infect Immun 40, 759-765.

Cisar, J. O., David, W. A., Curl, S. H. \& Vatter, A. E. (1984). Exclusive presence of lactose-sensitive fimbriae on a typical strain (WVU45) of Actinomyces naeslundii. Infect Immun 46, 453-458.

Cisar, J. O., Vatter, A. E., Clark, W. B., Curl, S. H., Hurst-Calderone, S. \& Sandberg, A. L. (1988). Mutants of Actinomyces viscosus T14V lacking type 1 , type 2 , or both types of fimbriae. Infect Immun 56, 2984-2989.

Cisar, J. O., Barsumian, E. L., Siraganian, R. P., Clark, W. B., Yeung, M. K., Hsu, S. D., Curl, S. H., Vatter, A. E. \& Sandberg, A. L. (1991). Immunochemical and functional studies of Actinomyces viscosus $\mathrm{T} 14 \mathrm{~V}$ type 1 fimbriae with monoclonal and polyclonal antibodies directed against the fimbrial subunit. J Gen Microbiol 137, 1971-1979.

Clark, W. B., Wheeler, T. T. \& Cisar, J. O. (1984). Specific inhibition of adsorption of Actinomyces viscosus T14V to saliva-treated hydroxyapatite by antibody against type 1 fimbriae. Infect Immun 43, 497-501.

Donkersloot, J. A., Cisar, J. O., Wax, M. E., Harr, R. J. \& Chassy, B. M. (1985). Expression of Actinomyces viscosus antigens in Escherichia coli: cloning of a structural gene (fimA) for type 2 fimbriae. J Bacteriol 162, 1075-1078.

Gibbons, R. J. \& Nygaard, M. (1970). Interbacterial aggregation of plaque bacteria. Arch Oral Biol 15, 1397-1400.

Gibbons, R. J., Hay, D. I., Cisar, J. O. \& Clark, W. B. (1988). Adsorbed salivary proline-rich protein 1 and statherin: receptors for type 1 fimbriae of Actinomyces viscosus T14V-J1 on apatitic surfaces. Infect Immun 56, 2990-2993.

Handley, P. S., Carter, P. L. \& Fielding, J. (1984). Streptococcus salivarius strains carry either fibrils and/or fimbriae on the cell surface. J Bacteriol 157, 64-72.

Handley, P. S., Carter, P. L., Wyatt, J. E. \& Hesketh, L. M. (1985). Surface structures (peritrichous fibrils and tufts of fibrils) found on Streptococcus sanguis strains may be related to their ability to 
coaggregate with other oral genera. Infect Immun 47, 217-227.

Hsu, S. D., Cisar, J. O., Sandberg, A. L. \& Kilian, M. (1994). Adhesive properties of viridans streptococcal species. Microb Ecol Health Dis 7, 125-137.

Hughes, C. V., Kolenbrander, P. E., Andersen, R. N. \& Moore, L. V. H. (1988). Coaggregation properties of human oral Veillonella spp.: relationship to colonization site and oral ecology. Appl Environ Microbiol 54, 1957-1963.

Hughes, C. V., Andersen, R. N. \& Kolenbrander, P. E. (1992). Characterization of Veillonella atypica PK1910 adhesin-mediated coaggregation with oral Streptococcus spp. Infect Immun 60, $1178-1186$.

Hultgren, S. J., Duncan, J. L., Schaeffer, A. J. \& Amundsen, S. K. (1990). Mannose-sensitive haemagglutination in the absence of piliation in Escherichia coli. Mol Microbiol 4, 1311-1318.

Irvin, R. T., Doig, P., Lee, K. K., Sastry, P. A., Paranchych, W., Todd, T. \& Hodges, R. S. (1989). Characterization of the Psendomonas aeruginosa pilus adhesin: confirmation that the pilin structural protein subunit contains a human epithelial cellbinding domain. Infect Immun 57, 3720-3726.

Johnson, J. L., Moore, L. V. H., Kaneko, B. \& Moore, W. E. C. (1990). Actinomyces georgiae sp. nov., Actinomyces gerencseriae sp. nov., designation of two genospecies of Actinomyces naeslundii, and inclusion of $A$. naeslundii serotypes II and III and Actinomyces viscosus serotype II in A. naeslundii genospecies 2 . Int J Syst Bacteriol 40, 273-286.

Jones, C. H., Pinkner, J. S., Roth, R., Heuser, J., Nicholes, A. V., Abraham, S. N. \& Hultgren, S. J. (1995). FimH adhesin of type 1 pili is assembled into a fibrillar tip structure in the Enterobacteriaceae. Proc Natl Acad Sci USA 92, 2081-2085.

Kolenbrander, P.E. (1982). Isolation and characterization of coaggregation-defective mutants of Actinomyces viscosus, Actinomyces naeslundii, and Streptococcus sanguis. Infect Immun 37, $1200-1208$

Kolenbrander, P. E. \& Andersen, R. N. (1986). Multigeneric aggregations among oral bacteria : a network of independent cellto-cell interactions. J Bacteriol 168, 851-859.

Kolenbrander, P. E. \& Andersen, R. N. (1990). Characterization of Streptococcus gordonii (S. sanguis) PK488 adhesin-mediated coaggregation with Actinomyces naeslundii PK606. Infect Immun 58, 3064-3072.

Kolenbrander, P. E. \& London, J. (1992). Ecological significance of coaggregation among oral bacteria. Adv Microb Ecol 12, 183-217.

Kolenbrander, P. E. \& London, J. (1993). Adhere today, here tomorrow: oral bacterial adherence. J Bacteriol 175, 3247-3252.

Kolenbrander, P. E., Inouye, Y. \& Holdeman, L. V. (1983). New Actinomyces and Streptococcus coaggregation groups among human oral isolates from the same site. Infect Immun 41, 501-506.

Kolenbrander, P. E., Andersen, R. N. \& Moore, L. V. H. (1989). Coaggregation of Fusobacterium nucleatum, Selenomonas flueggei, Selenomonas infelix, Selenomonas noxia, and Selenomonas sputigena with strains from 11 genera of oral bacteria. Infect Immun 57, 3194-3203.

Kuehn, M. J., Heuser, J., Normark, S. \& Hultgren, S. J. (1992). P pili in uropathogenic Escherichia coli are composite fibres with distinct fibrillar adhesive tips. Nature 356, 252-255.

Laemmli, U. K. (1970). Cleavage of structural proteins during the assembly of the head of bacteriophage T4. Nature 227, 680-685.

Lee, K. K., Sheth, H. B., Wong, W. Y., Sherburne, R., Paranchych, W., Hodges, R. S., Lingwood, C. A., Krivan, H. \& Irvin, R. T. (1994). The binding of Pseudomonas aeruginosa pili to glyco- sphingolipids is a tip-associated event involving the C-terminal region of the structural pilin subunit. Mol Microbiol 11, 705-713.

Lindberg, F., Lund, B., Johansson, L. \& Normark, S. (1987). Localization of the receptor-binding protein adhesin at the tip of the bacterial pilus. Nature 328, 84-87.

London, J. \& Allen, J. (1990). Purification and characterization of a Bacteroides loescheii adhesin that interacts with procaryotic and eucaryotic cells. J Bacteriol 172, 2527-2534.

Mclntire, F. C., Vatter, A. E., Baros, J. \& Arnold, J. (1978). Mechanism of coaggregation between Actinomyces viscosus T14V and Streptococcus sanguis 34. Infect Immun 21, 978-988.

Maryanski, J. H. \& Wittenberger, C. L. (1975). Mannitol transport in Streptococcus mutans. J Bacteriol 124, 1475-1481.

Moch, T., Hoschützky, H., Hacker, J., Kröncke, K.-D. \& Jann, K. (1987). Isolation and characterization of the $\alpha$-sialyl- $\beta$-2,3galactosyl-specific adhesin from fimbriated Escherichia coli. Proc Natl Acad Sci USA 84, 3462-3466.

Nesbitt, W. E., Beem, J. E., Leung, K.-P. \& Clark, W. B. (1992). Isolation and characterization of Actinomyces viscosus mutants defective in binding salivary proline-rich proteins. Infect Immun 60, 1095-1100.

Nyvad, B. \& Kilian, M. (1987). Microbiology of the early colonization of human enamel and root surfaces in vivo. Scand J Dent Res 95, 369-380.

Rudel, T., Scheuerpflug, I. \& Meyer, T. F. (1995). Neisseria PilC protein identified as type-4 pilus tip-located adhesin. Nature 373, $357-359$

Schneewind, O., Model, P. \& Fischetti, V. A. (1992). Sorting of protein A to the staphylococcal cell wall. Cell 70, 267-281.

Schneewind, O., Fowler, A. \& Faull, K. F. (1995). Structure of the cell wall anchor of surface proteins in Staphylococcus aureus. Science 268, 103-106.

Towbin, H., Staehelin, T. \& Gordon, J. (1979). Electrophoretic transfer of proteins from polyacrylamide gels to nitrocellulose sheets : procedure and some applications. Proc Natl Acad Sci USA 76, 4350-4354.

Uhlin, B. E., Norgren, M., Båga, M. \& Normark, S. (1985). Adhesion to human cells by Escherichia coli lacking the major subunit of a digalactoside-specific pilus-adhesin. Proc Natl Acad Sci USA 82, $1800-1804$.

Weiss, E. I., London, J., Kolenbrander, P. E., Hand, A. R. \& Siraganian, R. (1988). Localization and enumeration of fimbriaassociated adhesins of Bacteroides loescheii. J Bacteriol 170, 1123-1128.

Yeung, M. K. (1992). Conservation of an Actinomyces viscosus T14V type 1 fimbrial subunit homolog among divergent groups of Actinomyces spp. Infect Immun 60, 1047-1054.

Yeung, M. K. (1995). Construction and use of integration plasmids to generate site-specific mutations in the Actinomcyes viscosus T14V chromosome. Infect Immun 63, 2924-2930.

Yeung, M. K. \& Cisar, J. O. (1988). Cloning and nucleotide sequence of a gene for Actinomyces naeslundii WVU45 type 2 fimbriae. J Bacteriol 170, 3803-3809.

Yeung, M. K. \& Cisar, J. O. (1990). Sequence homology between the subunits of two immunologically and functionally distinct types of fimbriae of Actinomyces spp. J Bacteriol 172, 2462-2468.

Yeung, M. K., Chassy, B. M. \& Cisar, J. O. (1987). Cloning and expression of a type 1 fimbrial subunit of Actinomyces viscosus T14V. J Bacteriol 169, 1678-1683.

Received 9 July 1996; revised 21 October 1996; accepted 24 October 1996. 